\title{
Exploring environmental connection: ecological network opportunities in the Shahdagh National Park, Azerbaijan
}

\author{
Emil JabrayiloviD \\ Institute of Geography, Azerbaijan National Academy of Sciences, \\ 115 H. Javid Ave, Baku, AZ1143, Republic of Azerbaijan \\ $\checkmark$ e.jabrayilov@geo.science.az
}

\begin{abstract}
The high growth rate of consumption of natural resources by people in the last century have seriously and negatively affected ecosystems and led to the loss of biodiversity. At present, it is important to take the necessary measures to ensure sustainable development and biodiversity conservation. Ecological networks play an important role in maintaining and controlling the stability and balance of communication between ecosystem complexes. For this purpose, the possibility of creating an ecological network that includes core areas, buffer zones, ecological corridors and restoration areas in the section of Shamakhi district of the Shahdagh National Park was explored. The designated buffer zone of the national park includes 14 villages and 1 settlement type administrative unit. Mountainous landscapes predominate in the area, and the absolute height ranges from 500-200 m. Riverbeds, intermountain depression, mountain passes, trails and forests which should be planted in the areas we offer, were considered as main factors during the construction of ecological corridors in the national park and the buffer zones. The materials obtained from the literature and our field studies, also, vector and raster data were used during the site identification. The data was processed in software such as ArcGIS 10, ERDAS Imagine, Global Mapper, Google Earth, etc. Existing ecosystems were identified, and areas were calculated in separate elements of the ecological network in the study area.
\end{abstract}

Keywords: ecological network, ecological corridors, buffer zones, ecosystems, Shahdagh National Park, Azerbaijan

Article history: received 01.03.2020; revised 20.05.2020.

For citation: Jabrayilov E. Exploring environmental connection: ecological network opportunities in the Shahdagh National Park, Azerbaijan. RUDN Journal of Ecology and Life Safety. 2021;29(1):92-102. http://dx.doi.org/10.22363/2313-2310-2021-29-1-92-102

(C) Jabrayilov E., 2021

(c) This work is licensed under a Creative Commons Attribution 4.0 International License https://creativecommons.org/licenses/by/4.0/ 


\title{
Изучение связи с окружающей средой: возможности экологической сети в Шахдагском национальном парке, Азербайджан
}

\author{
Э. Джабраилов (D) \\ Институт географии, Наџиональная академия наук Азербайджана, \\ Азербайджанская Республика, AZ1143, Баку, пр-кт Г. Джавида, д. 115 \\ emil.jabrayilov@gmail.com
}

\begin{abstract}
Аннотация. Высокие темпы роста потребления природных ресурсов людьми в прошлом веке оказали значимое негативное воздействие на экосистемы и привели к утрате биоразнообразия. В настоящее время важно принять необходимые меры для обеспечения устойчивого развития и сохранения биоразнообразия. Экологические сети играют важную роль в поддержании и контроле стабильности и баланса связи между экосистемными комплексами. С этой целью изучена возможность создания экологической сети, включающей основные территории, буферные зоны, экологические коридоры и зоны восстановления на участке Шемахинского района Шахдагского национального парка. Обозначенная буферная зона национального парка включает 14 деревень и 1 административную единицу поселкового типа. Здесь преобладают горные ландшафты, абсолютная высота которых колеблется в пределах 500-200 м. Русла рек, межгорные впадины, горные перевалы, тропы и леса, которые должны быть засажены на предлагаемых территориях, рассматривались как основные факторы при создании экологических коридоров в национальном парке и буферных зонах. При идентификации участка использованы материалы, полученные из литературы и собственных полевых исследований, а также векторные и растровые данные. Обработка данных осуществлялась в ArcGIS 10, ERDAS Imagine, Global Mapper, Google Earth и др. Существующие экосистемы идентифицированы, а площади рассчитаны в отдельных элементах экологической сети в районе исследования.
\end{abstract}

Ключевые слова: экологическая сеть, экологические коридоры, буферные зоны, экосистемы, Шахдагский национальный парк, Азербайджан

История статьи: поступила в редакцию 01.03.2020; принята к публикации 20.05.2020.

Для цитирования: Jabrayilov E. Exploring environmental connection: ecological network opportunities in the Shahdagh National Park, Azerbaijan // Вестник Российского университета дружбы народов. Серия: Экология и безопасность жизнедеятельности. 2021. T. 29. № 1. C. 92-102. http://dx.doi.org/10.22363/2313-2310-2021-29-1-92-102

\section{Introduction}

The high rate of growth using of natural resources by the human in the last century have seriously negatively affected ecosystems and led to the biodiversity loss [1]. Strengthening ecological coherence and sustainability as a prerequisite for biodiversity conservation and sustainable development is currently increasing its relevance. Ecological networks have been developing for over 40 years as a model in order to preserve the integrity of environmental processes. Since the 1980s, several national environmental programs have been developed in Cen- 
tral and Eastern Europe based on the concept of a "polarized landscape" [2] by Russian geographer Boris Rodoman. In most other regions of Europe, the ecological network model is based mainly on MacArthur and Wilson's Theory of Island Biogeography [3]. Since the 1990s, regional and national programs aimed at expanding and coordinating protected areas have been accelerated in the countries of Western Europe, North America, Latin America and Australia.

Generally, these approaches, which are classified as ecological networks share two common goals: preserving ecosystems to facilitate the protection of species and the environment and reducing the impact of human activities on biodiversity by promoting sustainable use of natural resources or increasing the value of managed landscapes [4]. Ecological networks represent a general approach to how they can be applied at the local level by distributing specific functions in various fields, depending on their environmental value and their potential [5].

Protected areas are essential for protecting biodiversity and supporting environmental processes $[6 ; 7]$. It is highly advisable to plan ecological networks in protected areas that play a special role in maintaining environmental integrity. In practice, due to different land ownership and management forms, it is possible for ecological networks to cover some or all of the protected areas. The differentiation of protected areas in terms of type, purpose, and use requires that management mechanisms should be organized according to local conditions.

The Shahdag National Park, which studied in the article, is the largest national park in the South Caucasus and covers mainly the middle and high mountains of the Greater Caucasus in Azerbaijan. The current territory of the national park, created in 2006, is $130,508.1$ hectares. The main goals of the establishment of the national park are restoration and management of mountain ecosystems, protection of endemic and endangered species, carrying out scientific research, environmental education of the population, development of ecotourism and so on ${ }^{1}$. The territory of the national park, combining the important and unique mountain landscapes of the country, begins at an altitude of $1000 \mathrm{~m}$ above sea level and continues to the highest peaks (Bazarduzu mt, $4466 \mathrm{~m}$; Shahdagh mt, $4243 \mathrm{~m}$; Tufandagh mt, $4191 \mathrm{~m}$; Bazaryurd mt, $4126 \mathrm{~m}$; Yaridagh mt, $4116 \mathrm{~m}$ ) of the country. The national park, which borders the Russian Federation from the north, covers the mountainous parts of six administrative regions of Azerbaijan - Oghuz, Gabala, Ismayilli, Shamakhi, Guba and Gusar. There are two main highways from the capital towards the national park. One of them in the direction of Baku, Shamakhi, Ismayilli, Gabala and Oghuz regions, and another one towards Baku, Guba, and Gusar regions.

Defining and establishing an ecological network in the park is essential for the development of the national park, including the protection of the environment and biodiversity, reducing the impact of human activities and ultimately ensuring sustainable development of ecosystems.

\footnotetext{
${ }^{1}$ Regulation on Shahdag National Park of the Republic of Azerbaijan. 2008. Available from:
} http://www.e-qanun.az/framework/16011 (accessed: 22.02.2020). 


\section{Materials and methods}

Study area. The study area is part of the Shahdag National Park within Shamakhi District and its surrounding areas (Figure 1). Coordinates: $40^{\circ} 41^{\prime}-$ $40^{\circ} 50^{\prime} \mathrm{N} ; 8^{\circ} 28^{\prime}-48^{\circ} 42^{\prime} \mathrm{E}$. The designated buffer zone of the National Park includes 14 villages and 1 settlement type administrative unit. The creation of this protected area dates back to 1968. The Pirgulu State Nature Reserve, established at that time, played an exceptional role in the protection of mountain landscapes, vegetation, soils, and valuable fauna. Since 2006, the nature reserve has been part of the Shahdagh National Park.

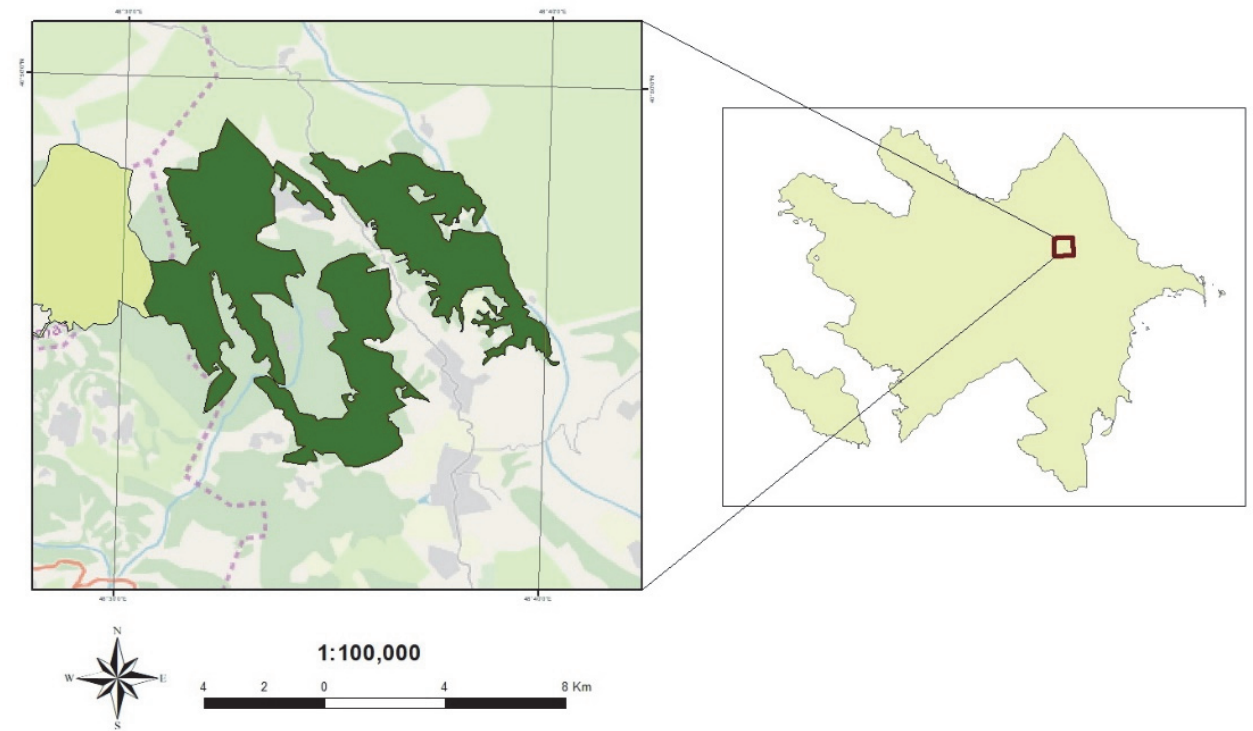

Figure 1. Field of study, Shamakhi section of Shahdag National Park

Methodological approach. The conceptual model of the research used the ecological network model [1]. Literature and field research materials, vector and raster data were used in the analysis. Topographic maps, satellite images (from Sentinel 2 and Landsat 8), such as raster data, were used to obtain information about the area, boundaries, and infrastructure of the park. The vector data was included in the development of ecological network elements. ArcGIS 10, ERDAS Imagine 15, Global Mapper, Google Earth software programs were used during data processing.

\section{Analysis and discussion}

Natural resources. As in other sections of the Shahdagh National Park, the study area which is included in the Shamakhi region has a complicated mountainous terrain. The mountainous landscape is predominant in the area and the absolute height varies between 500-2200 m above sea level (Figure 2). The main mountain systems are Mount Pirqulu, Girkhbulag, Gart, Alifdagh and Jangi. Aghsuchay river and its tributaries Kirkhbulag, Avakhil, Marmarakhar, Sis and others, and Pirsaatchay river with its Janut (Mustafalichay) tributary is the base of the river network in the area. On the banks of Janut river, there is a forest of Taxus. Here the forests are of two tiers. While oak, maple, and ash-trees are over in 
the first tier, the second half contains the taxus forests [8]. There are landslides and slides on the mountain slopes. The area is more widespread with oak-hornbeam, beech-hornbeam, beech-oak forests at the middle uplands, and forest-steppe, steppe and subalpine meadows at the low highlands.

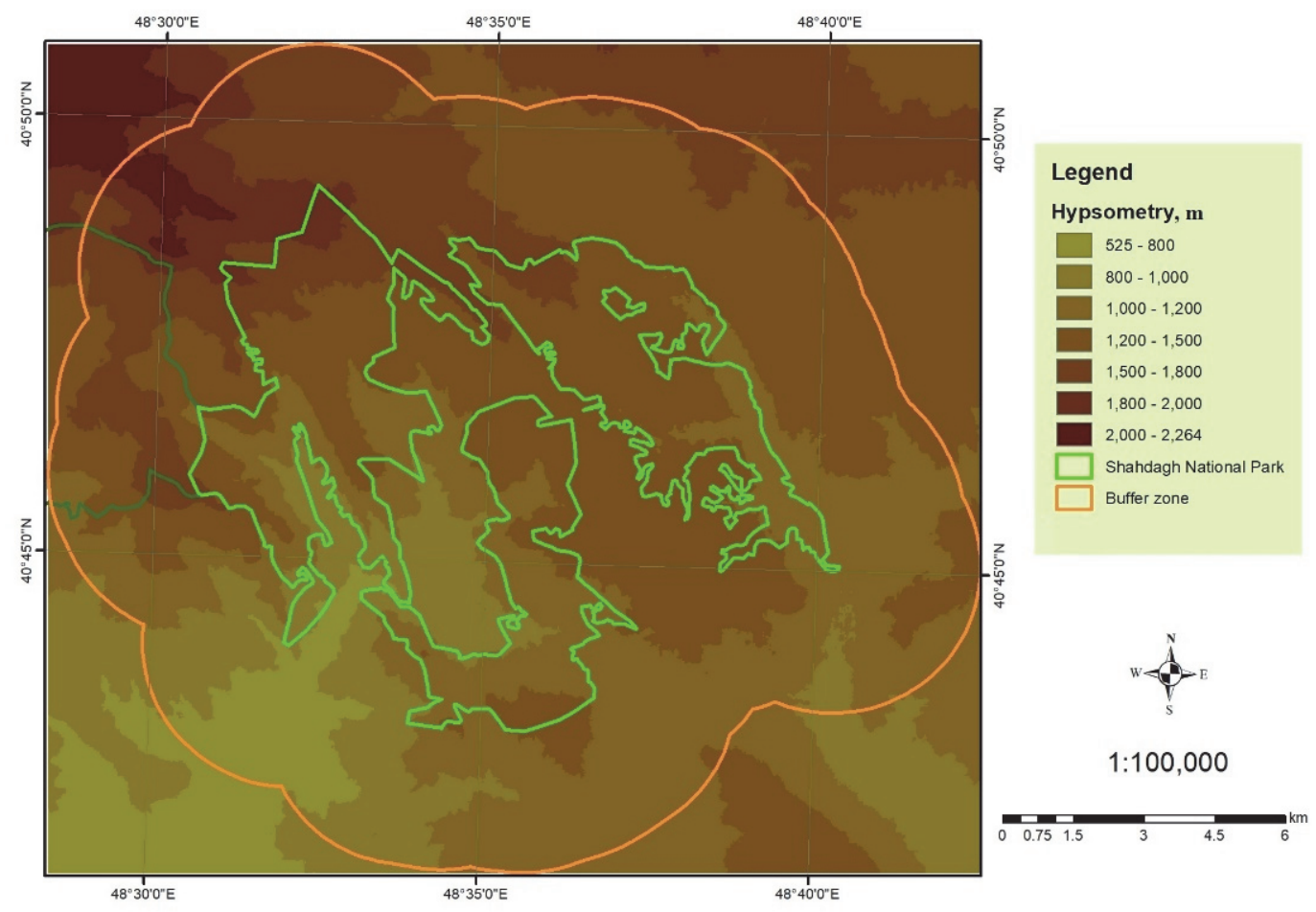

Figure 2. Hypsometric map of the study area

The mountainous relief of the area is one of the key factors affecting climate formation. Here the temperature and precipitation indicators vary depending on the altitude. The average annual temperature in the Pirgulu stationary is $8{ }^{\circ} \mathrm{C}$. The average temperatures in January and July are $-4{ }^{\circ} \mathrm{C}$ and $19.7^{\circ} \mathrm{C}$, respectively. Annual precipitation varies between 600 and $900 \mathrm{~mm}$ depending on the altitude. Spring and autumn precipitation become more intensive and stronger. July and August are the dryest periods. Heavy rains occur frequently and cause the soil to wash and eroded $[9 ; 10]$.

The relief and climatic conditions of the national park also contributed to the enrichment of biodiversity. Iberian and eastern oak, eastern beech, Caucasian hornbeam, ash-trees, maple and taxus, and types of shrubs, including hawthorn, medlar, blackberries, rose hips, etc., predominate in the forests. Among the species of animals - brown bear, deer, wild boar, wolf, eagle, fox, badger, jackal, rabbit; poultry, pheasants, quail, woodpecker, etc., settled here.

Legislative base. Relevant legislative acts adopted to protect these and other beauties of nature are very important elements in this area. Thus, the basis of this legislative framework is the laws of nature protection and ecology adopted in the country, a number of international conventions and protocols that have been ratified. Examples of these laws, currently in force at the local level, are the Law of the Republic of Azerbaijan on Environmental Protection (1999), the Law on 
Environmental Security (1999), the Low on Specially Protected Nature Territories and Objects (2000), the Low on Ecological Education and Awareness (2002).

At the international level, such documents as the Ramsar Convention (1971), the Bonn Convention (1979) and the Berne Convention (1979), and the Convention on Biological Diversity (1992) were signed. The Ramsar Convention is the first major international agreement in this regard. This agreement marks the first time a major and significant step towards international protection of wetlands such as brooks, rivers, lakes, and springs [11]. The convention, signed in Bonn, aims at the protection of migratory species, while the Berne Convention provides for the protection of fauna and flora within international cooperation. Although the Convention on Biological Diversity ${ }^{2}$, adopted in 1992 in Rio de Janeiro, does not play a direct role in the creation of ecological networks, it is a universal document with two important provisions. The first is that the law recognizes sovereignty within each state with respect to biodiversity, and the second is the declaration of state responsibility for the protection of biodiversity.

Each of the aforementioned international documents has been ratified by the legislature of the Republic of Azerbaijan. It is important to take into account such environmental-oriented legislations when establishing an ecological network, including its elements in national parks.

According to the Article 10-1 of the law of the Republic of Azerbaijan on Specially Protected Natural Territories and Objects ${ }^{3}$ : "The sanitary protection zone of protected areas (equivalent to a buffer zone) shall be established within $3,000 \mathrm{~m}$ of the entire perimeter of the land and water boundaries of protected natural areas".

According to this law, a number of admissible activities, as well as prohibitions, apply in these areas. Scientific-research activities, environmental monitoring and control of ecosystem changes, fire protection and maintenance of forest areas, use of land for economic purposes, as well as grasslands and pastures, restoration of biodiversity and natural ecosystems activities, recreational purposes, use of mineral water and other therapeutic resources, sport and amateur hunting of fish and other aquatic bioresources are types of activities with permitted. But otherwise, construction of new settlements, placement, and operation of enterprises that create environmental hazards, including chemical, nuclear energy, and metallurgical industries, geological exploration, extraction and processing of minerals, use of forests, using of agrochemicals and pesticides, introduction of species not compatible with local fauna and flora, and activities that violate the hydrological regime of the area and affect the soil fertility are prohibited.

Article 29 of the Law on Wildlife of the Republic of Azerbaijan ${ }^{4}$ states that individuals and legal entities must ensure the protection of the habitat, breeding conditions and migration routes of animals when carrying out any activities that may have a detrimental effect on the state of wildlife. According to the law, there

${ }^{2}$ Convention on Biological Diversity, United Nations, June 5, 1992. Available from: https://www.cbd.int/doc/legal/cbd-en.pdf (accessed: 22.02.2019).

${ }^{3}$ Law of the Republic of Azerbaijan on Specially Protected Natural Territories and Objects. 2000. Available from: http://www.e-qanun.az/framework/617 (accessed: 22.02.2019).

${ }^{4}$ Law of the Republic of Azerbaijan on Wildlife. 1999. Available from: http://www.eqanun.az/framework/3850 (accessed: 22.02.2020). 
should establish and implement measures designed to protect the habitat, reproductive conditions and migration routes of fauna species when designing and implementing human-designed activities (settlements, businesses, installations, pipelines, transport routes, etc.). Operation of such facilities and the application of technology without the protection of animals and their habitat are prohibited.

Elements of the ecological network in the national park. The creation of an ecological network in the national park, along with the rationale for the legislation, must also be analyzed with the elements of the network. Such elements include core areas, ecological corridors, buffer zones, and recreational areas.

Core areas are landscapes, species and ecosystems that are protected and have particular value. Such areas are defined by landscape diversity, existing ecosystems and surface cover configuration. The development of these parameters also leads to an increase in species. The larger the area and the greater the environmental conditions, the lower the risk of species depletion. Wide range of core areas results in better conservation of biodiversity in the region, leading to higher migration activities of the species.

The area covered by the national park is designated as a core area (Figure 3). The total area of the core area is 5896 ha, most of which is covered by oakhornbeam, beech-hornbeam, beech-oak forest ecosystems of low and middle uplands (Table 2). As a protected area, human activities in core areas are governed by relevant legislative acts. Since the territory has the status of a national park, in accordance with the regulation there is possible to create zones as follows to ensure the functioning of the national park: zones where special legal protection regime is applied, tourism and recreation zones, service zones for tourists and others, economic and production zones. The distribution of the territory of the national park by zones of protection with special regimes is defined by the Cabinet of Ministers of the Republic of Azerbaijan based on the presentation of the Ministry of Ecology and Natural Resources of the Republic of Azerbaijan.

Ecological corridors, as key elements of ecological networks, play an extremely important role in facilitating the migration of animals and plants in specially protected areas. In today's rapid population growth, ecological corridors are essential for the long-term survival and sustainable development of biodiversity [12].

Increasing human exposure to nature also leads to an increase in the number of depleted species. For one reason or another, the migration process is disrupted, which leads to the depletion of species of animals and plants that correspond to local conditions, and the inability to return to the process at a later stage. This tendency can be effectively prevented by protecting nature and restoring ecological corridors.

During the construction of the ecological corridors in the Shahdag National Park, riverbeds, intermountain depressions, mountain passes, trails, and forests, which should be planted in the proposed areas, were taken as a basis (Figure 3). Physiognomicly, all three types of ecological corridors [13] were applied in the study area, taking into account the presence of lines, steppe-stones, and landscapes. Line corridors have been identified along the $200 \mathrm{~m}$ width and $72 \mathrm{~km}$ length of the river beds. The type of stepping-stone corridors facilitates the establishment of interconnection between the core areas through planting trees and greenery. For this purpose, this type of ecological corridors has been identified in four different directions. The landscape type of ecological corridors has been proposed for the or- 
ganization of communication between core areas and linear corridors near the Sis and Kaleybugurt villages, covering relatively large areas.

The ecological corridor features play a role in the linking of species habitat and restoration of natural biological migration. Since the selection of species as a target during corridor identification is required, we have focused on mammalian species such as brown bears, roe deers, wild boars, badgers and rabbits living in the park. Because these animals prefer moving in the forest and vegetated green areas, their lifestyle is also considered in the study. The habitats of such animals are suitable sites for the development of ecological processes, with the role of migration "sources" [14].

Buffer zones are areas that are responsible for maintaining and protecting the core areas or are particularly important for maintaining balance in geosystems [15]. Functionally it divided into protective and geosystem buffer zones. Buffer zones serve to improve ecosystems, preserve and enhance the geosystem balance, and neutralize the environmental impacts between agricultural and protected areas in the ecological network.

The buffer zone of the study area was set at 3,000 $\mathrm{m}$ along the border of the core area with the admission of the relevant article of the Law of the Republic of Azerbaijan "On Specially Protected Natural Areas and Objects". The total area is 19400 hectares. The main ecosystems are mountain-forests, mountain meadow, forest-steppe, subalpine meadows and seliteb zones. This zone includes 14 villages and 1 settlement (Table 1). In the ecosystems located here, it is only possible to engage in economic and other activities in the manner prescribed by the legislation we have analyzed above.

Table 1

List of settlements in the buffer zone

\begin{tabular}{cccc}
\hline No. & Settlements (villages) & No. & Settlements (villages) \\
\hline 1 & Damirchi & 9 & Kechmaddin \\
2 & Archiman & 10 & Galadarasi \\
3 & Avakhil & 11 & Ahmedli \\
4 & Yusif Mammadaliyev s. & 12 & Talishnuru \\
5 & Chukhuryurd & 13 & Dadagunash \\
6 & Nagharakhana & 14 & Chaghan First \\
7 & Sis & 15 & Chaghan Second \\
8 & Galeybughurd & & \\
\hline
\end{tabular}

Restoration areasare created for the restoration of biological or geomorphological conditions of the territory. Typically, such zones are areas that are not profitable, despite the various efforts and methods used, or have greatly deteriorated as a result of anthropogenic impacts. Therefore, the restoration is inevitable to the recovery of such soils and saving the ecosystems. Such areas may become core areas or buffer zones at the next stage.

A number of problems or questions may arise during the design of the restoration areas. One of the problems may be against the interest of any stakeholder in the selection of such areas and in making decisions for the common good. Coordination of rehabilitation activities, effective use of resources for positive results, and decision-making based on the advice of scientific researchers and experts du- 
ring implementation are basic terms. These conditions have been taken into account when determining the restoration areas around the national park in the study. Such areas have been identified along the northern and southern boundaries and within the interior structure of the national park, especially in areas where natural ecosystems are essential for restoration (Figure 3). Over time and the recovery process, showing positive results, the boundaries of the national park will also be expanded at the expense of such areas.

Table 2

Ecological network elements and ecosystems in the study area

\begin{tabular}{lcc}
\hline \multicolumn{1}{c}{ Network elements } & Area, ha & Ecosystems \\
\hline Core area & 5896 & $\begin{array}{c}\text { Oak-hornbeam, beech-hornbeam, } \\
\text { beech-oak forests ecosystems } \\
\text { of low and medium highlands }\end{array}$ \\
\hline $\begin{array}{l}\text { Ecological corridors: } \\
\text { - linear } \\
\text { - stepping-stone } \\
\text { - landscape }\end{array}$ & 1437 & $\begin{array}{c}\text { Mountain forests, mountain meadows, } \\
\text { river ecosystems }\end{array}$ \\
\hline Buffer zone & 64 & $\begin{array}{c}\text { Mountain forests, mountain meadows, } \\
\text { Restoration areas }\end{array}$ \\
\hline
\end{tabular}

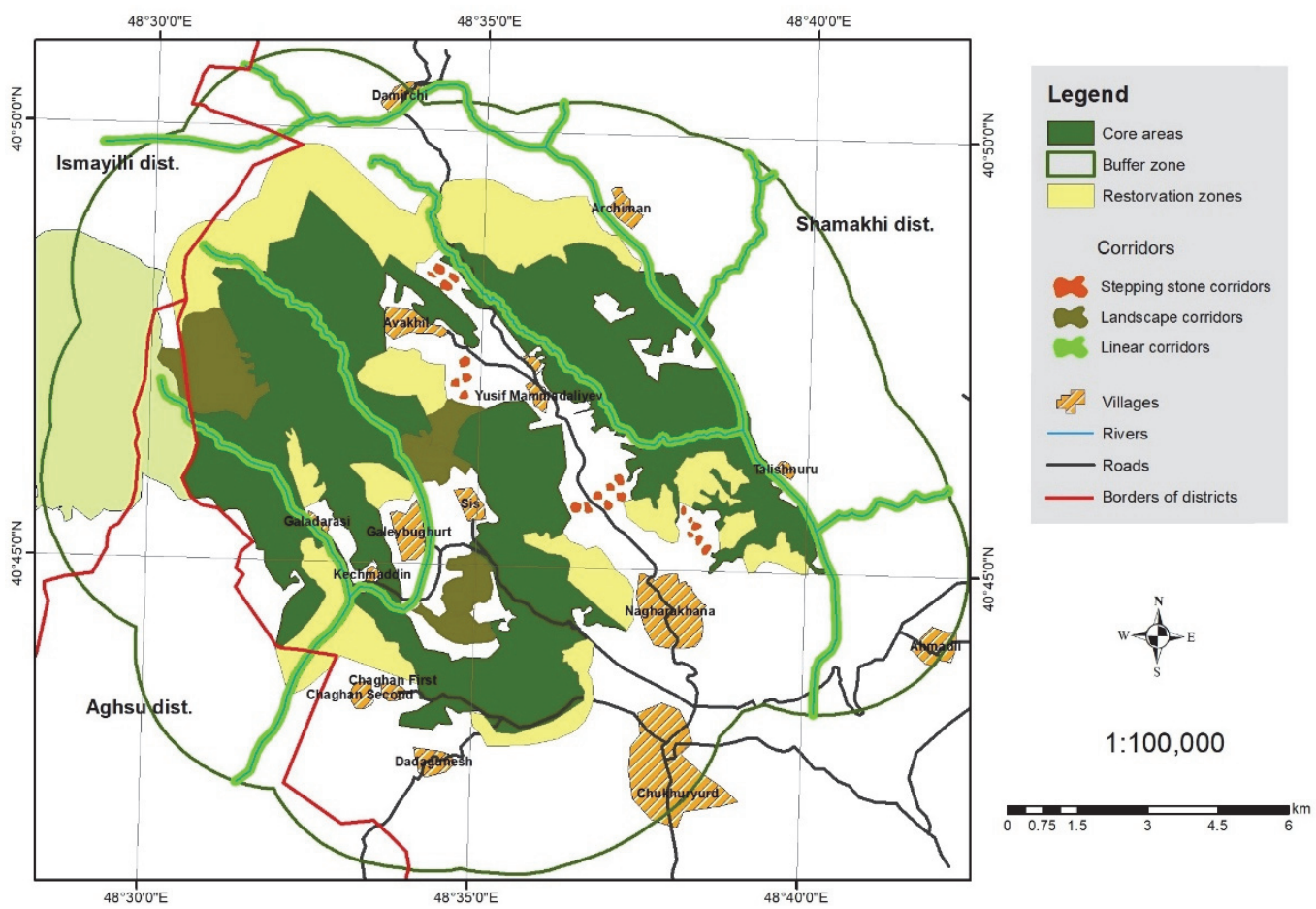

Figure 3. Ecological network model of the study area

\section{Proposals}

Ecological networks as a model represent an ecosystem approach that promotes the conservation of biodiversity and the sustainable use of natural resources. The basis of this approach is that economic development is not possible 
without the effective management of ecosystems for the benefit of society [16]. The involvement of various sectors of the economy and society in the management of ecosystems is an important factor for the implementation of the approach. Proposals for the study area to address such issues are as follows:

1. The management of ecosystems, including all elements of the ecological network, should be centralized and the impact of adjacent ecosystems should be taken into account.

2. Reduce economic activity, which negatively affects biodiversity in the development of ecosystem management programs, and promote the conservation and sustainable use of biodiversity.

3. To achieve the integrity of the ecological network, long-term goals should be set, and scientific approaches, knowledge of local communities and all forms of information should be taken into account.

4. Measures aimed at the protection and sustainable use of natural complexes require a broader and more comprehensive approach. Therefore, there is a need to develop additional activities and ecosystem services in residential areas. Fruit and its processing, expanding beekeeping, collecting medicinal herbs, selling local crafts, handicrafts, and stimulating activities for local businesspersons will lead to improved living standards and at the same time protecting biodiversity.

5. During the implementation and execution of this approach, scientific institutions such as geography, zoology and botany, the relevant executive government authorities, Ministry of Ecology and Natural Resources, as well as environmentally-oriented public associations, NGOs, and local businesspersons, stakeholders should be actively involved to the programs.

\section{Conclusion}

The paper proposes an environmental network model in the study area, for the first time in Azerbaijan, which selected as a pilot site. Core area and buffer zones were determined following the legislation, and ecological corridor types and restoration areas have been identified taking into account natural conditions in this study. An electronic map was developed for the network model, and the area of each network element was calculated within the relevant ecosystem.

It became clear that the theoretical part of the research, connectivity of ecosystems and natural habitats play an important role in sustainability. Therefore, relevant legislative and strategic documents and programs should be developed to integrate environmental networks into public policy at the national level. Since this approach does not require large financial resources, it is advisable to apply it in the future to the whole country.

The ecological network model presented in the article will help to conserve biodiversity, reduce anthropogenic impacts, eliminate environmental barriers, and promote appropriate forms of land use. However, the more sophisticated optimum configuration of the environmental network to promote regional sustainable development can be determined by future research. 


\section{References}

[1] Bennett G, Mulongoy KJ. Review of experience with ecological networks, corridors and buffer zones. Technical Series No. 23. Montreal: Secretariat of the Convention on Biological Diversity; 2006.

[2] Rodoman BB. Landscape polarization as a means of biosphere and recreational resources conservation. Resources, Environment, Settlement. Moscow: Nauka Publ.; 1974. p. 150-162. (In Russ.)

Родоман Б.Б. Поляризация ландшафта как средство сохранения биосферы и рекреационных ресурсов // Ресурсы, среда, расселение. М.: Наука, 1974. С. 150-162.

[3] MacArthur RH, Wilson EO. The theory of island biogeography. Princeton, N.J.: Princeton University Press; 1967.

[4] Bennett G, Wit P. The development and application of ecological networks: a review of proposals, plans and programmes. Amsterdam: AIDEnvironment; 2001.

[5] Bennett G. Integrating biodiversity conservation and sustainable use: lessons learned from ecological networks. Gland: IUCN; Cambridge; 2004.

[6] Lee TM, Jetz W. Future battlegrounds for conservation under global change. Proc. $R$. Soc. B. 2008;275:261-1270. https://doi.org/10.1098/rspb.2007.1732

[7] Pressey RL, Cabeza M, Watts ME, Cowling RM, Wilson KA. Conservation planning in a changing world. Trends Ecol. Evol. 2007;22:583-592 https://doi.org/10.1016/j.tree.2007.10.001

[8] Mammadov GSh, Khalilov MY. Forests of Azerbaijan. Baku; 2002. (In Azerb.)

[9] Hajiyev GA, Rahimov VA. Climate characteristics of administrative regions of the Azerbaijan SSR. Baku; 1977. (In Azerb.)

[10] Ibrahimov T. National parks of Azerbaijan. Baku; 2015. (In Azerb.)

[11] The Ramsar Convention Manual: a guide to the Convention on Wetlands (Ramsar, Iran, 1971). 6th ed. Gland: Ramsar Convention Secretariat; 2013.

[12] Chang SC, Tu CJ, Chen HY. Ecological corridor in the urban area: case study in Kaohsiung City, Taiwan. Pract. Period. Hazard. Toxic Radioact. Waste Manage. 2010;14: 76-88. https://doi.org/10.1061/(ASCE)HZ.1944-8376.0000018

[13] Climenco V, Trombitki I, Andreev A. The ecological network: a way to the nature conservation in Moldova. Chisinau: Societatea Ecologica BIOTICA; 2002.

[14] Chen CD, Meurk DC, Ignatieva EM, Stewart HG, Wu SJ. Identifying and evaluating functional connectivity for building urban ecological networks. Acta Ecologica Sinica. 2015;35:6414-6424. (In Chin.) https://doi.org/10.5846/stxb201402160263

[15] Martino D. Buffer zones around protected areas: a brief literature review. Electron. Green J. 2001:1:1-20.

[16] Simenova V, Bos E, Jongman R, Zingstra H. Implementation of ecological networks in different socio-economic contexts. Guiding principles based on experiences in Central and Eastern Europe. Wageningen: Alterra; 2009.

\section{Bio note:}

Emil Akif oghlu Jabrayilov, scientific researcher, Institute of Geography, Azerbaijan National Academy of Sciences. E-mail: emil.jabrayilov@gmail.com

\section{Сведения об авторе:}

Джабраилов Эмиль Акиф огль, научный сотрудник, Институт географии, Национальная академия наук Азербайджана. E-mail: emil.jabrayilov@gmail.com 